\title{
DINAMIKA KAMPUNG KOTA BERKELANJUTAN DI TENGAH PANDEMI COVID-19
}

\author{
Ni Putu Suda Nurjani \\ ${ }^{1}$ Program Studi Teknik Industri, Fakultas Teknik, Universitas Mahendradatta \\ JI. Ken Arok No.12, Peguyangan, Denpasar, Bali 80115 \\ Email: suda.nurjani@gmail.com
}

\begin{abstract}
Abstrak - Kampung kota sebagai salah satu wujud permukiman di Indonesia, dimasukkan dalam kategori permukiman kumuh (Slums). Kehidupan perkotaan yang dipandang mampu memberikan harapan penghidupan bagi masyarakat desa, membawa arus bawaan yaitu perpindahan penduduk sehingga ruang publik yang ada di perkotaan menjadi semakin berkurang. Lokalitas yang terkandung pada tatanan kampung akan memberi karakter bagi pembentukan semangat urbanisme baru yang sesuai dengan karakter masyarakat. Perwujudan urbanitas dan ruang kota yang berkelanjutan dapat dicapai dengan rumusan prinsip-prinsip yang telah lama diwariskan oleh nenek moyang bangsa ketika membentuk sebuah kampung tradisional. Namun, di tengah pandemi covid-19 yang melanda dunia, keberadaan kampung kota di Indonesia mengalami gejolak yang cukup besar. Masyarakat urban yang dulu nya membentuk sebuah kampung di daerah perkotaan, kini memilih kembali pulang ke daerah asal akibat minimnya pekerjaan yang tersedia di kota. Banyak pekerja dirumahkan tanpa pesangon, dengan tuntutan hidup yang besar, membuat kaum urban memilih pulang kembali ke kampung halaman. Kawasan permukiman yang sebelumnya tumbuh tidak direncanakan, kini ditinggalkan. Ilegal settlement yang dahulu meresahkan, semenjak pandemi berubah menjadi kampung tidak bertuan. Ketika sebuah permukiman yang awalnya dianggap sebagai sebuah beban dan merusak citra kawasan kini ditinggalkan, apakah kota menjadi lebih baik, apakah kehidupan sosial masyarakat kota menjadi baik atau sebaliknya. Fenomena ini memerlukan sebuah kajian mendalam. Citra buruk kota yang sebelumnya selalu dibebankan pada permukiman kumuh, kini bisa dilihat bagaimana permasalahan agraria yang sebenarnya. Dalam permukiman kumuh tumbuh sistem kekerabatan baru yang saling menguatkan antar orang perantauan, membentuk sebuah ruang publik informal yang mendukung kaum individualistis yang hidup di kota.
\end{abstract}

Kata Kunci : Urbanisasi; Kampung Kota; pandemi covid-19

\begin{abstract}
Kampung kota as one form of settlement in Indonesia, included in the category of slums. Urban life is seen as able to provide livelihoods for the villagers, bringing innate currents that are the displacement of the population so that the open land in the city becomes less. The locality contained in the village order will give character to the formation of a new spirit of urbanism that is in accordance with the character of the community, rooted in a sustainable settled ideology. The realization of sustainable urbanity and urban space can be achieved by formulating principles that have long been inherited by the nation's ancestors when forming a traditional village. However, in the midst of the covid-19 pandemic that hit the world, the existence of hometowns in Indonesia experienced considerable turmoil. Urban communities that used to form a village in urban areas, have now chosen to return home due to the lack of jobs available in the city. Many workers are housed without severance, with great demands for life, making urbanites choose to return home. The settlement area, which had previously grown unplanned, is now abandoned. Illegal settlement is troubling, since the pandemic turned into a no-man's land. When a settlement that was originally considered a burden and damaged the image of the area is now abandoned, whether the city is for the better, whether the social life of the city community becomes good or vice versa. This phenomenon requires an in-depth study. Bad image of the city that was previously always charged to slums, can now be seen how the real agrarian problems. In the slums grew a new kinship system that strengthened each other among overseas people, forming an informal public space that supported the individualists living in the city.
\end{abstract}

Keywords : Urbanization; Kampung kota; covid-19 pandemic 


\section{PENDAHULUAN}

Permukiman kota di Indonesia secara umum dibagi menjadi tiga tipe. Pertama adalah tipe permukiman yang terencana (well-planned), dengan penataan infrastruktur dan fasilitas yang lengkap dan dapat dijangkau oleh kendaraan bermotor. Tipe kedua adalah tipe kampung, dengan rumah-rumah yang berada di dalam, kebanyakan tidak dapat dijangkau dengan mobil maupun motor. Tipe ini adalah tipe permukiman lama/asli kota-kota di Indonesia. Sedangkan tipe ketiga adalah permukiman pinggiran/kumuh (squatter) yang banyak bermunculan pada ruang-ruang marjinal kota, seperti tepi sungai atau di tanah milik negara. Tipe ini juga sering disebut dengan tipe kampung illegal (Sullivan, 1980). Kampung, dalam bahasa Melayu berarti sebuah kompoun tertutup (enclosed compound).

Dalam bahasa Minangkabau, kampung berkaitan dengan kehidupan yang sarat dan konsisten akan penerapan nilai-nilai tradisional. Di Aceh, kampung merupakan keseluruhan komunitas di sebuah desa (Atman, 1974). Kampung sebagai sebuah enclosed compound di dalam kota memliki karakteristik tersendiri, di mana kehidupan sebuah desa (village) masih terdapat di dalamnya, yang masih nampak pada sistem sosial dan budaya yang mengikat. Akibatnya, keberadaan kampung ini mau tidak mau harus menjadi perhatian dan bagian dari kehidupan perkotaan, termasuk dalam proses perencanaan dan penataan kota. Hal ini tentunya mendorong kampung sebagai salah satu bagian pembentuk sebuah kota di Indonesia, sebagai bagian yang relevan atau sebuah alternatif pemecahan problem perkotaan. Seperti dikutip dari pernyataan:

Like almost everything, urban development in Indonesia took a dualistic course (...): tale of two cities. This Implies that we have formal high stancard, rational settlement/urban development copied from developed countries, especially the 'west'. Super imposed on it, we easily can find the second city, indigenous, informal yet very natural and human in its development, locally known as the 'kampung'. (Indrayana, Silas, 1985, p.4, dikutip dari Sandi a Siregar, Bandung the Architecture of a City in Development, 1990)

Pendapat ini menyatakan bahwa kampung sebenarnya sebuah bentuk asli dari kota-kota di Indonesia. Terlepas dari formalitas bentuk maupun aturan-aturan pembangunan, nampaknya kampung lebih menggambarkan segi humanitas dan urbanitas kehidupan kota yang saat ini mulai dicari kembali oleh negaranegara maju melalui konsep New Urbanism. Kampung kota merupakan fenomena yang banyak terjadi terutama di Negara-negara berkembang, dimana pertumbuhan pola sosial dan budaya masyarakat berbeda dengan tuntutan kehidupan kota, jika dipandang dari sudut universalisme nilai dan kehidupan perkotaan modern.

Pada dasarnya pengertian kampung kota yang dapat disepakati semua pihak belum pernah dapat dirumuskan. Hal ini kemungkinan disebabkan oleh perbedaan di dalam cara pandang maupun disiplin ilmu yang digunakan oleh para pakar. Namun yang menarik dari pernyataan-pernyataan tersebut adalah tersirat adanya kepadatan dan kemiskinan dan samasama menyatakan bahwa kampung merupakan bagian yang tidak dapat dipisahkan dari kota. Sebagai kesatuan integral kota, maka kampung merupakan salah satu komponen dalam pembentukan struktur kota, yaitu sebagai kawasan permukiman. Hasil penelitian Soegijoko dan Bulkin,1994 (dalam Tjiptoherijanto, 1999) menyebutkan bahwa, pada tahun 1920, proporsi penduduk perkotaan hanya 5,8 persen dari seluruh penduduk yang ada. Senada dengan Soegijoko dan Bulkin, Supas (1995) juga mengungkapkan bahwa, tingkat urbanisasi di Indonesia telah mencapai 35,91 persen. Fenomena urbanisasi dalam kaitannya dengan ilmu planologi selain dipandang sebagai proses berpindahnya masyarakat pedesaan ke perkotaan juga dipandang sebagi proses mengkotanya suatu pedesaan. Kampung adalah ciri kehidupan bermukim yang dapat dianggap sebagai tatanan permukiman tradisional sebelum masuknya perencanaan permukiman modern khususnya di Indonesia. Tipologi permukiman ini merupakan akar dari 
pertumbuhan kota-kota di Indonesia karena kampung pada dasarnya merupakan embrio pertumbuhan, sehingga penataan suatu kawasan kota perlu memperhatikan eksistensi kampung ini sebagai titik tolak penataan. Kampung dapat menjadi sumber peradaban, kreativitas maupun budaya kota karena kondisi dan keterbatasan yang ada.

\section{Urbanitas sebagai Hakekat Hidup di Perkotaan}

Wiryomartono (1999) menyebutkan bahwa urbanitas adalah kondisi efisien di perkotaan sehingga sumber-sumber dapat terkelola dan terkendali, yang mudah dicapai bila tempat tinggal mantap dan menetap. Urbanitas berada di lingkungan binaan manusia yang memiliki struktur dan wujud yang bisa dan layak ditinggali, yang oleh karenanya adalah proses yang mempertautkan sekelompok manusia dan tempat tinggalnya melalui aktivitas sosial ekonomi yang dicapai melalui kegiatan membangun dan membina kehidupan bermasyarakat. Dari pendapat tersebut dapat disimpulkaan bahwa urbanitas merupakan kinerja dari sebuah kota, dimana sumbersumber daya yang ada dapat memiliki peran masing-masing sehingga menciptakan keterkaitan dan hubungan yang saling menguntungkan. Kuncinya adalah terletak pada upaya untuk mendefinisikan kembali komponen-komponen kota dengan perannya masing-masing sebagai kekuatan-kekuatan untuk berproduksi. Sehingga apakah yang baru dari urbanitas? Nampaknya selama ini sistem perkotaan telah mengabaikan karakteristik urbanitas tersebut. Kekuatan ekonomi dan upaya penyesuaian terhadap pasar global dan modernitas telah menghilangkan dan menyingkirkan satu atau lebih komponen urbanitas tersebut. Urbanitas bukanlah hal baru, melainkan urbanitas adalah hakekat bagaimana seharusnya 'berkota'. Sehingga apapun bentuk sistem ekonomi dan sosial yang dianut, maka harus dapat menciptakan kondisi dan peran yang berimbang bagi seluruh komponen pembentuk kota dalam membentuk urbanitas. Karena itu upaya untuk mendefinisikan kembali esensi dan karakteristik berkota merupakan langkah awal yang nampaknya ditempuh untuk memunculkan apa yang disebut 'urbanisme baru' yang bukan hal baru.

\section{New Urbanism: Physical Approach}

Gerakan ini sebenarnya bukan merupakan hal baru karena esensi yang terkandung di dalamnya, merupakan kriteria-kriteria yang sebagaian besar telah ada pada tatanan kotakota khususnya di Eropa pada abad pertengahan. Karena itu, maka gerakan yang muncul di Amerika ini merupakan kebangkitan dari tradisionalisme yang ada di Eropa (the Revival of Traditionalism). Konsep gerakan ini berkembang dilatarbelakangi oleh perhatian terhadap permasalahan urban sprawl yang merupakan persoalan utama perkotaan modern yang terjadi di Amerika dan keinginan untuk mengembangkan ruang kota yang berkelanjutan. New urbanisme adalah sebuah gerakan untuk mereformasi perencanaan dan perancangan lingkungan binaan dengan tujuan untuk meningkatkan kualitas hidup masyarakat kota. Dengan misi untuk mengembalikan konsepsi komunitas dan lingkungan dalam konteks perencanaan dan perancangan kota, maka gerakan ini mengeluarkan beberapa prinsip antara lain bahwa lingkungan sebuah komunitas harus mengandung hal-hal:

1. Walkability, yaitu bahwa seluruh tempat di komunitas harus dapat dijangkau melalui berjalan melalui perancangan sistem pedestrian yang nyaman dengan kriteria seperti perimeter block building, parkir tersembunyi, dan ruang jalan yang tidak terlalu lebar.

2. Connectivity, yaitu keterkaitan jaringan jalan yang memudahkan pergerakan dan pejalan, dengan menciptakan pedestrian dan fasilitas publik yang berkualitas.

3. Mixed Use \& Diversity, yaitu penggunaan yang multi fungsi baik di dalam komunitas, di dalam blok maupun di dalam bangunan berupa fungsi-fungsi hunian dan fungsifungsi lain yang sesuai. Selain itu berupaya untuk memunculkan keragaman penghuninya seperti usia, kelas sosial, adat/budaya dan ras.

4. Mixed Housing, berupa keragaman hunian baik tipe, harga maupun ukurannya

5. Quality Architecture \& Urban Design, yaitu menekankan pada segi keindahan, 
kenyamanan dan penciptaan sense of place bagi lingkungan komunitas, dan perancangan yang memperhatikan skala manusia.

6. Traditional Neighbourhood Structure, yaitu pemunculan tata ruang tradisional seperti ruang publik, kejelasan posisi pusat (center) dan ujung (edge) komunitas dan hierarki ruang lingkungan yang jelas

7. Increased Density, yaitu upaya untuk meningkatkan kepadatan dengan fungsi yang beragam dalam satu kesatuan sehingga menciptakan penggunaan sumber daya dan pelayanan yang lebih efisien.

8. Smart Transportation, yaitu jaringan transportasi dan sarana transportasi publik yang memadai yang saling terkait dengan wilayah lain, serta penciptaan pedestrian yang ramah yang memungkinkan aktivitas transportasi non kendaraan bermotor.

9. Sustainability, yaitu upaya untuk meminimalkan dampak lingkungan dari perkembangan dan kegiatan komunitas, penggunaan teknologi yang ramah lingkungan, penggunaan sumber daya yang efisien dan menciptakan suasana yang kondusif bagi kegiatan berjalan ketimbang berkendaraan (mobil).

10. Quality of Life, yaitu berupa sasaran akhir yang dituju dari penerapan berbagai prinsip di atas.

Gerakan ini menghasilan beberapa konsep perencanaan dan perancangan kota yang mencoba mengakomodasikan seluruh prinsip yang ada yaitu antara lain konsep mengenai pembangunan yang berorientasi pada sistem transit/transportasi (TOD), konsep perumahan dengan kepadatan tinggi dan konsep mengenai pemanfaatan tapak yang multifungsi, dengan fungsi hunian sebagai intinya, hingga konsep mengenai kota yang terpadu (compact city) berbasis pada lingkungan hunian.

\section{Kota dalam Tantangan Multidimensi}

Permasalahan dasar yang dihadapi oleh perkotaan, khususnya di Indonesia sebagai Negara berkembang (developing country) adalah terus berlangsung proses pertumbuhan (growth) yang berjalan secara paralel dengan perubahan baik secara fisik dan non fisik, menuju pada suatu kondisi tertentu sebagai hasil tekanan kekuatan ekonomi, politik, sosial maupun budaya masyarakat. Isu ini menjadi titik tolak dalam mengatasi dan memunculkan solusi bagi setiap permasalahan yang muncul di perkotaan. Pertumbuhan di kota berpangkal tolak dari semakin meningkat populasi yang terjadi baik secara alami maupun melalui urbanisasi yang menyebabkan permintaan akan ruang (space) semakin meningkat. Hal ini didukung oleh adanya perubahan perilaku masyarakat penghuni kota baik perilaku sosial, budaya, ekonomi, politik maupun perilaku dalam penggunaan teknologi. Akibatnya, terjadi ekspansi, berupa meluasnya kota hingga merambah ke daerah-daerah penyangga dan intensifikasi ruang di pusat kota, baik melalui upaya daur ulang, air-right, underground-right atau upaya-upaya untuk berbagi ruang (sharing space) secara lokasi maupun waktu (Danisworo, 2002).

Melalui globalisasi dan modernisasi, kota-kota khususnya di Asia Tenggara menjadi obyek keseragaman dari suatu proses dan menjadi satu kesatuan dalam sistem kota internasional dengan corak universal. Namun di sisi lain simbol dan nilai budaya nasional juga menguat sebagai reaksi dari nilai-nilai yang datang. Maka disinilah terjadi proses lokalitas, sehingga apa yang terjadi saat ini adalah kotakota di Asia Tenggara termasuk di Indonesia merupakan simbiosis antara kepentingan global melalui modernitas sebagai dampak globalisasi dan tradisi yang masih melekat kuat pada struktur budaya masyarakat yang member keunikan bagi kota-kota tersebut.

\section{Pembangunan Kawasan Kota Berkelanjutan}

Pembangunan kota berkelanjutan adalah proses pembangunan (lahan, kota, bisnis, masyarakat, dsb) yang berprinsip "memenuhi kebutuhan sekarang tanpa mengorbankan pemenuhan kebutuhan generasi masa depan". Salah satu faktor yang harus dihadapi untuk mencapai pembangunan berkelanjutan adalah bagaimana memperbaiki kehancuran lingkungan tanpa mengorbankan kebutuhan pembangunan ekonomi dan keadilan sosial. Sedangkan sebuah perkotaan yang 
berkelanjutan adalah sesuatu yang dapat di pelihara secara tidak pasti tanpa pengurangan yang berkembang dari kualitas yang bernilai di dalam dan di luar kota. Diharapkan dari sebuah pembangunan perkotaan yang berkelanjutan adalah sesuatu yang dapat dipelihara secara tidak pasti tanpa pengurangan yang berkembang dari kualitas yang bernilai di dalam dan di luar daerah dimana pembangunan sedang berjalan.

Konsep pembangunan berkelanjutan memiliki tahap-tahap dari yang paling sederhana (perhatian terbatas pada aspek lingkungan/ekologi) hingga yang paling berkembang (mencakup partisipasi masyarakat dalam pengambilan keputusan dan aspek pelestarian budaya). Konsep pembangunan berkelanjutan memiliki tahaptahap dari yang paling sederhana (perhatian terbatas pada aspek lingkungan/ekologi) hingga yang paling berkembang (mencakup partisipasi masyarakat dalam pengambilan keputusan dan aspek pelestarian budaya). Secara ekonomi, pembangunan kawasan perkotaan yang berkelanjutan harus menjamin terciptanya lapangan kerja bagi masyarakatnya, pemberdayaan masyarakat, dan peningkatan kesejahteraan masyarakatnya. Ketiga pilar tersebut di atas memiliki keterkaitan satu sama lain.

\section{Dinamika Kampung Kota di Tengah Pandemi Covid-19}

Kampung kota tumbuh sebagai magnet yang memicu terjadinya arus urbanisasi. Kampung kota identik dengan permukiman masyarakat yang heterogen, memiliki interaksi sosial tinggi akibat adanya perasaan senasib (orang rantau), memiliki latar belakang budaya beragam, dan jumlah ruang publik yang sangat terbatas. Sebelum pandemi covid-19, masyarakat kampung kota menjadi salah satu motor penggerak perekonomian perkotaan. Profesi sebagai pedagang, pekerja kantoran, pekerja serabutan, pembantu rumah tangga, dan profesi lain yang sebelumnya dipandang sebelah mata. Kembali ke rumah setelah beraktivitas, dimanfaatkan untuk berinteraksi dengan tetangga dan kerabat yang tinggal dalam satu kawasan. Kaum perempuan yang tidak memiliki pekerjaan teteap, membentuk sebuah komunitas baru, membuat usaha rumah tangga bekerjasama dengan ibu-ibu setempat, tidak memandang asal dan suku bangsa, bersama-sama berjuang hidup di tanah rantauan.
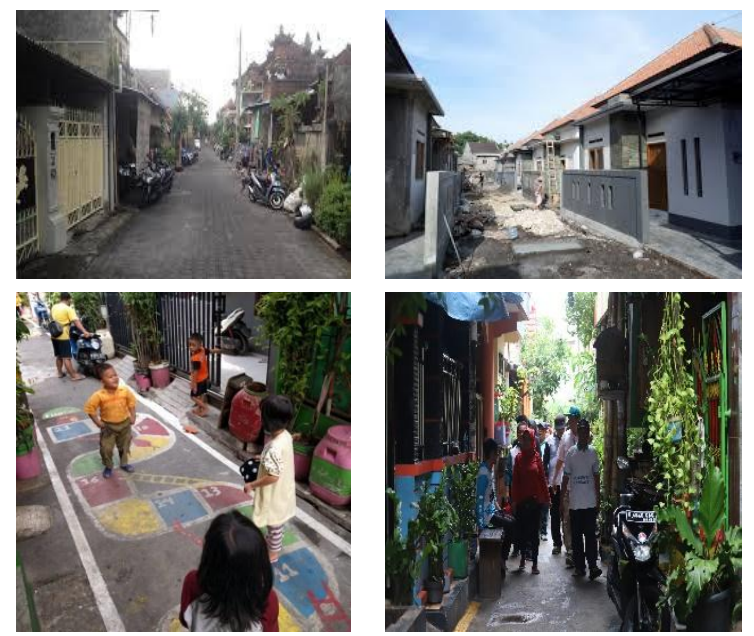

Gambar 1. Wajah Kampung kota di Indonesia Sumber:

https://www.google.com/search?q=kampung+kota \&tbm=isch\&ved=2ahUKEwi1nYeww7HuAhUR3XM BHe2mDUEQ2-

cCegQIABAA\&oq=kampung+kota\&gs $\quad \mathrm{l} p \mathrm{p}=\mathrm{CgNpb}$ WcQAzIECCMQJzICCAAyAggAMgIIADICCAAyBg gAEAUQHjIGCAAQBRAeMgYIABAIEB4yBggAEA gQHjIGCAAQCBAeOgQIABBDOgUIABCxAzoKCA AQsQMQgwEQQzolCAAQsQMQgwFQpGpYhnlg0 HpoAHAAeACAAbYBiAHUCpIBAzUuN5gBAKABA aoBC2d3cy13aXotaW1nwAEB\&sclient=img\&ei=cM 8LYLWIDJG6z7sP7c22iAQ\&bih=610\&biw=1280\&s afe $=$ strict\#imgrc $=B-M r 82 z J d B I 1 y M$

Namun, kondisi berbeda terlihat pada pusat permukiman kota. Karakteristik pola ketuhanan sangat tidak Nampak di dalam pola keruangan kota. Agama sudah tidak lagi menjadi suatu hal yang utama. Yang lebih dominan adalah ekonomi dan kedudukan sosial. Tata Letak tempat ibadah bukan lagi menjadi orientasi pembentukan ruang, melainkan yang menjadi orientasi utama adalah efisiensi dan efektivitas terhadap pemenuhan kebutuhan ekonomi. Masyarakat Kota cenderung bersifat individualistis. Jenjang sosial sangat jelas terlihat dalam wajah permukimannya. Masyarakat yang satu dengan yang lain, tidak pernah menjalin komunikasi yang baik. minimnya ruang publik untuk interaksi masyarakat. Perbedaan status sosial yang sangat mencolok dan kurangnya interaksi 
antar masyarakat, mendorong terjadinya kecemburuan sosial yang mengarah pada tindakan kriminalitas yang tinggi.

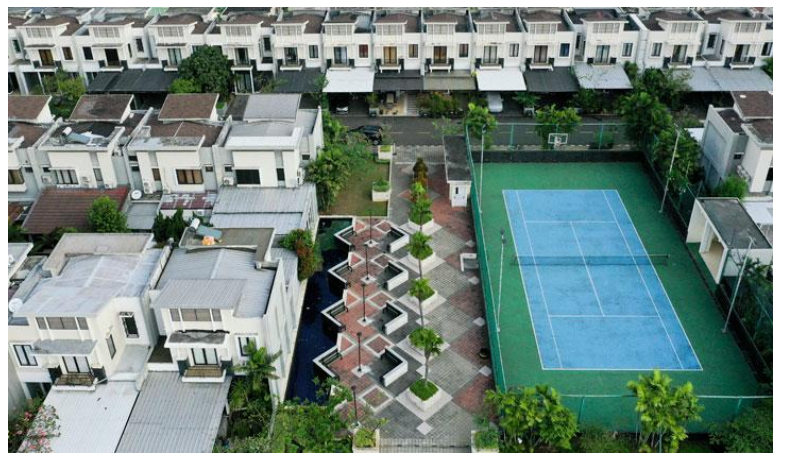

Gambar 2. Perumahan mewah kota Jakarta yang dibangun di atas atap Gedung Thamrin City

(Bagian bawah gedung perkantoran, mall, lantai teratas adalah perumahan). Sumber :

https://www.jawapos.com/labodetabek/26/06/2019/ viral-perumahan-mewah-di-atas-gedung-thamrincity-begini-faktanya/

Pandemi covid-19 berdampak pada kebiasaan bermukim di perkotaan. Pemberhentian karyawan selama pandemi mengakibatkan keterpurukan ekonomi masyarakat. Ketika masyarakat urban memilih kembali hidup di kampung halaman, kembali bergantung pada kehidupan bertani, kepadatan kota menjadi menurun sangat signifikan.

Pandemi covid-19 ini secara tidak langsung mereformasi konsep perencanaan dan perancangan kawasan perkotaan. Connectivity dan quality of life yang semula menjadi salah satu pertimbangan utama masyarakat untuk bermigrasi ke sebuah kawasan, pasca pandemi konsep utama perencanaan kawasan adalah smart integration area. Kebijakan work from home membatasi segala pergerakan manusia. Kewajiban physical distancing memberikan keterbatasan jarak dan interaksi antar individu. Kondisi ini membuat segala aktivitas manusia dikerjakan secara online dengan perantara teknologi digital. One building with multifunction space menjadi tagline pada setiap perencanaan kawasan terbangun. Interaksi sosial antar individu lebih banyak terjadi di dunia maya dengan memanfaatkan media sosial. Ruang publik yang sebelumnya dipergunakan untuk beramah tamah, kini digantikan dengan ruang maya untuk membangun ekonomi.

\section{KESIMPULAN}

Kampung kota sebagai cerminan heterogenitas masyarakat yang kaya dengan nilai lokal yang dibawa oleh setiap individu, mereformasi konsep dasar perencanaan kawasan perkotaan berkelanjutan. Pasca pandemi, konektivitas kampung kota tidak lagi menjadi pertimbangan utama. Peluang untuk bertahan hidup, walaupun dengan jarak tempuh yang jauh, masih tetap dipilih oleh masyarakat. Kristalisasi dinamika kampung kota diatas, merumuskan beberapa prinsip dasar yang dapat dipergunakan sebagai acuan dalam menciptakan kondisi urbanitas dan ruang kota yang berkelanjutan. Beberapa prinsip tersebut antara lain:

1. Menempatkan kampung kota sebagai bagian integral dari sistem perencanaan kota yang harus selalu diperhitungkan dan dipertimbangkan. Legalitas dan kepastian hukum terhadap eksistensinya melalui kekuatan poltik menjadi dasar yang paling berpengaruh pada upaya-upaya perbaikan dan pengembangannya. Kampung kota dapat berperan sebagai satu kesatuan lingkungan (neighbourhood).

2. Menciptakan keterkaitan antar lingkungan baik melalui keterkaitan ekonomi, sosial maupun budaya (makro) maupun lingkungan fisiknya (mikro), sehingga dapat menciptakan sistem perkotaan dan memberi legitimasi kuat pada eksistensi kampung (macro - micro linkage).

3. Menemukan kembali signifikansi kampung kota dari segi kesejarahan dan makna kultural tempat, untuk menentukan intervensi apa yang sebaiknya harus dilakukan dalam meningkatkan kualitasnya.

4. Keseimbangan yang proporsional antara kekuatan masyarakat melalui partisipasi dan tanggung jawab pemerintah dalam menciptakan sistem hunian perkotaan yang demokratis, plural dan toleran menuju masyarakat post-modern

Kampung kota sebagai titik tolak dalam menemukan urbanitas baru di Indonesia dapat menjadi kunci dalam membina kehidupan perkotaan yang lebih baik. Namun demikian, 
penelusuran mengenai prinsip-prinsip fisik nampaknya masih cukup jauh, karena masih harus menemukan kembali paradigma dan ideologi dalam bermukim di perkotaan yang berkarakteristik lokal. Penguatan karakter lokal tidak hanya sebagai langkah antisipasi melainkan sebagai kekuatan yang harus dipadukan dengan proses modernisasi.

\section{DAFTAR PUSTAKA}

Bahan Ajar Arsitektur Perkotaan. (2004) Staff Pengajar, Jurusan Arsitektur, Fakultas Teknik, Universitas Udayana, Bali

Budi Sudarwanto, G. H., Agung B Sarjono. (2017). Pemahaman Fenomena Pengetahuan Arsitektur Kampung Kota (Kasus: Kampung Bustaman Berbasis Kuliner). NALARs Jurnal Arsitektur, 16(2), 145-154.

Danisworo, M. dan Martokusumo, W. (2003). Materi Perkuliahan Isu Kontemporer Perancangan Kota", Magister Arsitektur ITB, Bandung

Dias Aprilia Lindarni, W. H. (2014). Transformasi Kampung Kota Di Kawasan Segitiga Emas Kota Semarang (Studi Kasus: Kampung Sekayu Dan Kampung Petempen). Riptek, 8(2), 1-12.

Hermawan, A. (2001). Permasalahan Kampung Kota, dari Kumpulan Makalah Isu Kontemporer Perancangan Kota", Magister Arsitektur Institut Teknologi Bandung
Kausan, B. Y. (2019). Kampung-Kota: Permukiman Kumuh Di Kota Bandung Tahun 1965-1985. Universitas Negeri Semarang, Semarang.

Mirsa, Rinaldi. (2012). Elemen Tata Ruang Kota.Graha IImu, Yogyakarta

Raisya Nursyahbani, B. P. (2015). Kajian Karakteristik Kawasan Pemukiman Kumuh Di Kampung Kota (Studi Kasus: Kampung Gandekan Semarang). Teknik PWK, 4(2), 267-281. Retrieved from http://ejournals1.undip.ac.id/index.php/pwk

Soni Darmawan, T. B. U. (2018). Pola Pemanfaatan Ruang Terbuka Pada Pemukiman Kampung Kota. Vitruvian Jurnal Arsitektur, Bangunan, \& Lingkungan, 7(3), 127-136.

Sumintarsih, A. A. (2014). Dinamika Kampung Kota Prawirotaman Dalam Perspektif Sejarah Dan Budaya. Yogyakarta: Balai Pelestarian Nilai Budaya (BPNB) Yogyakarta.

http://kampungnesia.org/berita-kampung-kotadan-kota-kampung--tantanganperencanaan-kota-di-indonesia--1.html diakses 22 Januari 2021

https://rujak.org/mencari-definisi-dan-maknakampung-kota/ diakses 22 januari 2021 